\title{
Implications of Climate Change on Water Resource Management in Megacities in Developing Countries: Mexico City Case Study
}

\author{
Gloria Soto-Montes \\ Department of Social Sciences, Metropolitan Autonomous University (UAM) \\ Av. Vasco de Quiroga 4871, Cuajimalpa, 05348, D.F., Mexico \\ E-mail: g.sotomontes@gmail.com.
}

Marina Herrera-Pantoja (Corresponding author)

Queretaro Water Commission

Av. 5 de Febrero 35, Col. Las Campanas,Queretaro, Mexico

Tel: 52-442-294-5929_E-mail: hpmarina@yahoo.com

Received: November 5, 2015 Accepted: November 25, 2015

doi:10.5296/emsd.v5i1.8807ＵRL: http://dx.doi.org/10.5296/emsd.v5i1.8807

\begin{abstract}
More than half of the world's population currently lives in urban areas. The fastest growing megacities are occurring mainly in developing countries, where stresses on water systems already pose major challenges for governments and water utilities. Climate change is expected to further burden water resource management, putting at risk governments' ability to guarantee secure supplies and sustainable development. In this study, the significance of assessing the implications of climate change on water resources in megacities as an important component of the adaptation process is explored. The Mexico City Metropolitan Area (MCMA), one of the largest cities in the world, is presented as a case study. The downscaled outputs of the General Circulation Model GFDLCM2a for the A1B and B1 gas emissions scenarios for the period 2046-2081 and a statistical model were used to simulate the likely impacts of climate change in water resources and domestic water demand. The results showed that an increase in temperature and changes in precipitation patterns could increase household water demand for both scenarios, between $0.8 \%$ and $6.3 \%$ in the MCMA. The
\end{abstract}


future projections also estimated increases of $150 \%$ and $200 \%$ in events with rainfall intensity of more than $60 \mathrm{~mm} \mathrm{~d}^{-1}$ and $70 \mathrm{~mm} \mathrm{~d}^{-1}$ respectively, drawing attention to the critical impacts these changes may have on flood events. Despite the uncertainty of models projections, future climate change scenarios have proven to be a flexible guide to identify vulnerabilities of water resources and support strategic adaptation planning. In order to increase their adaptive capacity and resilience to the effects of an uncertain climate change, megacities should consider implementing an integrated water resources management approach that creates opportunities through adequate policies, new technologies, flexible frameworks and innovative actions.

Keywords: Climate change, Megacities, Water Resources Management, Implications

\section{Introduction}

Over $54 \%$ of the world's population currently lives in urban areas, and it is estimated that by $2050,70 \%$ of the total population will be living in urban areas (UNHABITAT, 2008). The fastest growing megacities (defined as large urban areas with more than ten million inhabitants) are occurring mainly in the developing countries of Asia, Africa and Latin America, where urban areas expand by an average of 1.2 million people per week (UNHABITAT, 2011). One of the main challenges for megacities is to ensure sustainable water supplies (UNICEF and WHO, 2012). The enormous volumes of water and extensive infrastructure required to meet water demand have frequently exceeded governments' ability to guarantee secure supplies, as well as creating severe environmental problems (World Bank, 2012; WWAP, 2012; Wu and Tan, 2012). In East Asia, for example, rapid economic growth, urbanization and population expansion have led to increasing water withdrawal, a lack of treatment facilities, river pollution, floods and the lack of an effective institutional framework for integrated water resources management (Wu and Tan, 2012). In India, about $50 \%$ of the urban population has poor quality water supply and sanitation services due to leakages, unauthorized connections, and other inefficiencies (World Bank, 2012). In Brazil, the poor quality of drinking water supply and sanitation means that many people suffer from infectious water-related diseases (UN, 2009).

Climate change is expected to exert further stresses on water resources management due to changes in temperature, precipitation patterns and extreme weather events, which in turn will impact urban water demands and exacerbate the vulnerability of these societies (IPCC, 2012). Megacities in developing countries are particularly sensitive to climate change due to their fragile institutions, poor public services, large populations and inadequate infrastructure (UNHABITAT, 2011). Consequently, they need to understand the risks posed by climate change in order to reduce their vulnerability and build their adaptive capacity and resilience (Hebbert and Jankovic, 2013).

In this study the significance of assessing the impact of climate change on water resources in megacities as an important component of the adaptation process is explored. The Mexico City Metropolitan Area (MCMA), one of the largest cities in the world with over 20 million inhabitants (INEGI, 2010), is presented as a case study. In the MCMA, as in many other megacities around the world, climate change is already altering the frequency and intensity of 
droughts and floods producing a significant impact on water availability (Güneralp et al., 2015). For example, in August 2009, the water level of one of the seven dams in the Cutzamala System was at its lowest recorded level and as a result, water supply service was reduced by $25 \%$ over several weekends. However, during the months of September and October (when precipitation is expected to be lower), severe precipitation events with intensities of over $70 \mathrm{~mm}_{\text {day }}{ }^{-1}$ caused floods that broke the western sewerage section and led to the overflow of the four rivers used to transport sewage, with significant social and economic implications (CONAGUA, 2009). A few months later, in February 2010, other extreme events with intensities of $109 \mathrm{~mm} \mathrm{day}^{-1}$ and $159 \mathrm{~mm}^{-1} \mathrm{y}^{-1}$ created a regional alert, causing flooding that affected public infrastructure and residential areas, mostly in low income neighborhoods (SACM, 2012a). One year later, in June 2011, the Tropical Storm Arlene brought torrential rainfalls exceeding a volume of water of $24 \mathrm{Mm}^{3}$ in less than 24 hours, leaving some areas with severe flooding and widespread damage of lives and property (Luege-Camargo, 2011).

This study investigates the likely impacts of future climate change on water resources management in megacities in developing countries. Firstly, the water resources in the MCMA area are characterized. Secondly, the downscaled outputs of the General Circulation Model GFDLCM2a for the A1B and B1 gas emissions scenarios for the period 2046-2081 are used to simulate future time series of water balance variables. Finally, a statistical model is used to investigate the effects of changing temperature and precipitation patterns on domestic water demand and the main vulnerabilities of the current system to climate change are explored.

\section{Adaptation to Climate Change}

According to the IPCC (2007), vulnerability is the degree to which a system is unable to cope with the adverse effects of climate change. Reducing vulnerability may increase a society's resilience by enabling it to adapt when exposed to a hazard (World Bank, 2008). Most studies on climate change impacts and adaptation at the city level have been undertaken in developed countries, such as England, Australia and USA and they have agreed that adaptation to climate change requires reducing cities' vulnerability and increasing their resilience (Farley et al., 2011; Hunt and Watkiss, 2011; Ekström et al., 2013). There are several adaptation measures available in water management that can help to reduce vulnerability to climate change impacts, such as rainwater collection, water conservation plans, water reuse, desalination, as well as improved efficiency standards (Bates et al., 2008). Similarly, a number of studies also highlight the importance of reviewing civil protection schemes; and limiting population expansion (Stern, 2006; World Bank, 2008). Adaptation to climate change is a dynamic phenomenon that requires political and social involvement to address unsustainable development (Pelling, 2011). Bates et al. (2008) make a distinction between autonomous and planned adaptation. Autonomous adaptation is considered a reactive action to climatic stimuli; it is not explicitly designed to offset climate change, but may reduce its impact. On the other hand, planned adaptation is a proactive action, resulting from deliberate policy decisions, and specifically taking account of climate change (Stern, 2006). Planned adaptation generates lower costs because problems are addressed beforehand as opposed to autonomous adaptation. In developing countries, autonomous adaptation is a more common 
approach. Policy options may be improved and re-designed based on the knowledge capacity of the water management situation without considering future climate change scenarios, given the uncertainties and complexities related to future projections (Giorgi et al., 20019). However, the function of climate change simulations is to provide a range of situations that might emerge, including changes in the availability of water resources, extreme events and changes in user demand. The decision to implement adaptation policies and their scope will impact the costs that cities may face. A balanced perspective of strategies for tackling climate change can be provided by adopting an Integrated Water Resources Management (IWRM) approach, which considers a range of supply and demand processes and actions that incorporates stakeholders' involvement in decision-making processes (Bates et al., 2008; Miller and Yates, 2005). Scenarios to model possible impacts of climate change should not only consider the local physical environment and environmental change, but also the potential influence of policy and socio-economic forces (World Bank, 2008).

\section{Mexico City Metropolitan Area Case Study}

\subsection{Area Description}

The climate of the Mexico City Metropolitan Area (MCMA) ranges from semi-arid in the north to temperate humid in the south. The north and centre display higher temperatures whereas the south and mountainous areas have lower temperatures. Mean annual temperature is $16.7^{\circ} \mathrm{C}$ in the north and $11^{\circ} \mathrm{C}$ in the south. Maximum temperatures of $32.5^{\circ} \mathrm{C}$ occur in April and May coupled with minimum temperatures of $-1^{\circ} \mathrm{C}$ in December and January. Average annual precipitation is approximately $668 \mathrm{~mm}$ in the north and $1306 \mathrm{~mm}$ in the south. Precipitation falls mainly from June through October. The southern portion of the basin is the most important natural recharge zone for the aquifer due to relatively higher levels of precipitation and the high permeability of its basalt rock. The Mexico Basin is composed of a lacustrine zone, a transition zone and a mountain zone.

The MCMA is set in a closed basin $2240 \mathrm{~m}$ above sea level, surrounded by mountains of volcanic origin reaching a height of over $5000 \mathrm{~m}$ above sea level. The city has an area of approximately $7866 \mathrm{~km}^{2}$. It is home to $18 \%$ of the country's population and generates $38 \%$ of Mexico's gross domestic product in an area equivalent to less than $0.3 \%$ of national territory (INEGI, 2010). The core area of MCMA includes 16 delegations in the Federal District, with a population over 8.85 million people (INEGI, 2010), and has extended to 58 municipalities in the State of Mexico with 11.25 million inhabitants and one municipality in Hidalgo. During the 20th century, the pattern of urban growth in the MCMA lacked formal planning, creating a city with conflicting water services. In the mid- $20^{\text {th }}$ century, the Federal District government banned the construction of new settlements in its territory, which resulted in the expansion of urban municipalities into the State of Mexico (Tortajada, 2006). The Federal District is divided into two large areas depending on their land use: the urban zone in the north and the conservation zone in the south (Figure 1). The conservation area was officially set up in 1987, under the protection of the Federal District Environment Secretary. The conservation area initially had a total of over 87,000 hectares of natural forest, grassland, wetlands and agricultural land, significantly contributing to the groundwater recharge of the 
aquifer, among other environmental services. Although urban development is prohibited and the area is designated for use by indigenous communities, it is subject to pressure from building companies, illegal human settlements and the growth of rural settlements (Aguilar, 2008; Wigle, 2010).

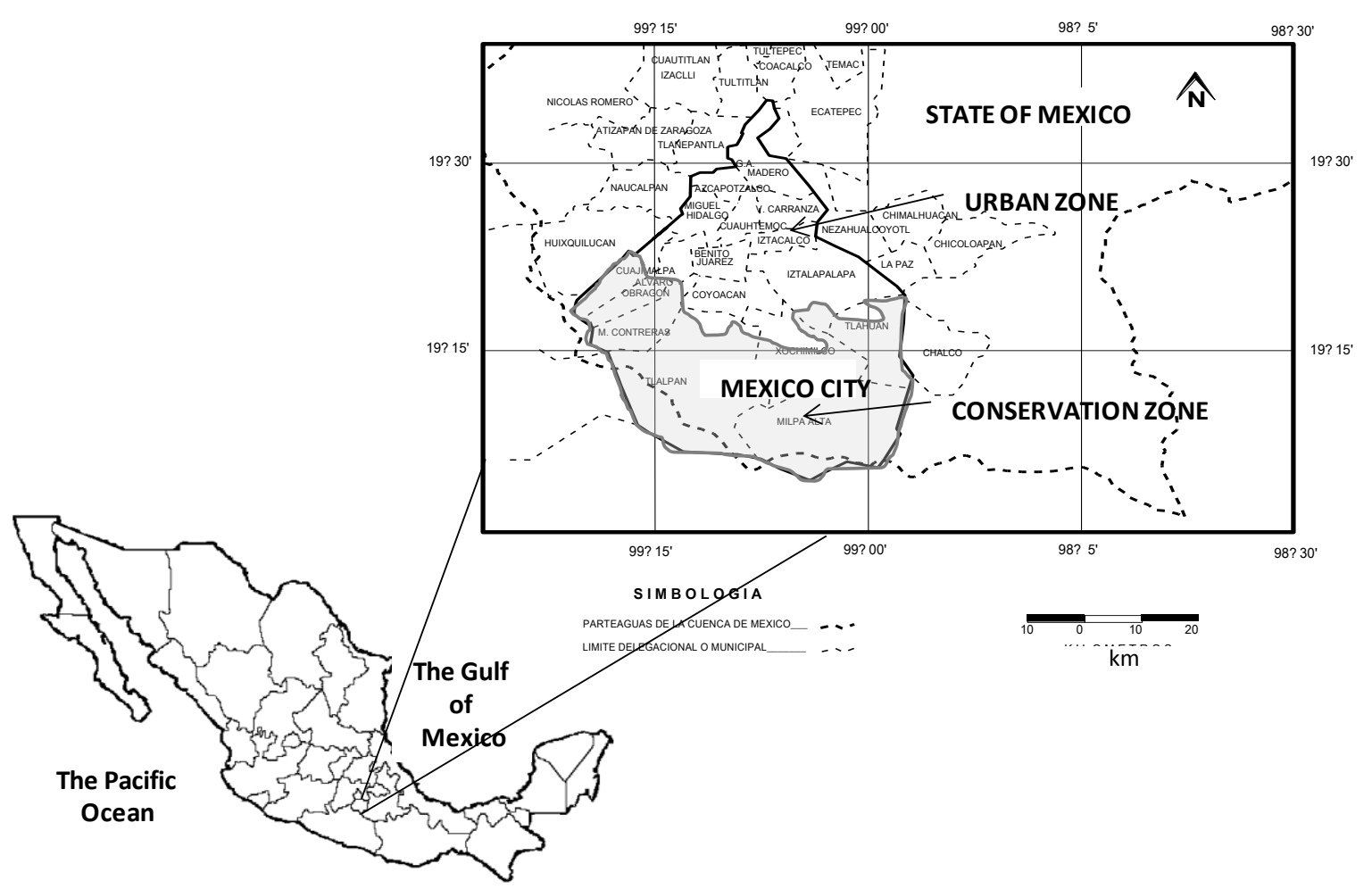

Figure 1. Map of the Mexico City Metropolitan Area (MCMA) showing the urban and conservation area.

\subsection{Water Resource Management}

The water planning processes must begin with characterizing the water resources encompassed in a given region. The MCMA consumes $61 \mathrm{~m}^{3} \mathrm{~s}^{-1}$ of water, over $70 \%$ of which comes from local sources, mostly from aquifers, the rest being imported from external sources. Estimations have indicated that water extraction exceeds the natural aquifer recharge capacity by approximately $22 \%$ (SACM, 2012). Increased pumping rates have resulted in ground subsidence, which lowered the central area by an average of $7.5 \mathrm{~m}$ over the past 100 years. This has resulted in extensive damage to the city's infrastructure, including building foundations and the water and sewerage system (Ortega-Guerrero et al., 1999).

The Federal District, the core area of the MCMA, alone consumes $31.9 \mathrm{~m} \mathrm{~s}^{-1}$, but $36 \%$ of this water is managed by the federal authorities. Some of the water is extracted from wells in the neighboring State of Mexico and most is imported from the Lerma and Cutzamala Basins, implying that local authorities do not have complete control over its management. Any temporary or permanent suspension of external water sources might affect a significant percentage of the population, particularly in the west part of the city, where water is obtained from these sources (SACM, 2008). As population density in the State of Mexico has 
increased, so has regional competition for water resources. Approximately $44 \%$ of the total water supplied in the Federal District is for domestic use; $21 \%$ for industrial, commercial and service use, while 35\% is lost through leaks and clandestine use (SACM, 2012). Illegal water infrastructure does not appear to be a major problem, being estimated at 3\% (Tortajada, 2006). Losses from leakages are the main concern and are due to the age of the pipe networks, their collapse in parts of the city due to land subsidence and the poor quality of the pipe network in peripheral areas (Lopez-Quiroz et al., 2009). Although 91.6\% of the population has a piped water connection to their homes and $94.2 \%$ have sewage, service is not supplied on a regular basis (World Bank, 2013). The Federal District is better served than the State of Mexico, yet 240 neighborhoods still suffer from regular water supply shortfalls, most of which are in low-income areas (Soto, 2008). In the MCMA the price of water is relatively cheap, due to a $50 \%$ government subsidy. The average daily water use is about 300 litters per person, this is more than double the amount of other cities in Mexico and Latin American (World Bank, 2013). Moreover, in the Federal District, only 1.3 million users have meters (62\%), meaning that $17 \%$ pay fixed rates while the remainder is exempted from payment (SACM, 2012). Service conditions are heterogeneous in the State of Mexico since each municipality administers its own water utility.

Groundwater recharge zones have been systematically urbanized (Marin et al., 2002), while all the rivers that used to flow into the central lakes of the basin are now connected to a drainage system. The drainage operation became a major concern since the past decade when the risk of major flooding in the city increased due to the land subsidence, and a sewage deficit of $12.9 \mathrm{Mm}^{3} \mathrm{~d}^{-1}$ caused by population growth. These problems resulted in the construction of a complex drainage system (CONAGUA, 2003; Cisneros-Iturbe and Dominguez-Mora, 2007). It also incorporated wastewater pumping plants in the Grand Canal with a capacity of $40 \mathrm{~m}^{3} \mathrm{~d}^{-1}$ (SACM, 2012a). Two recent major projects include an additional drainage canal called the East Outlet Tunnel (Emisor Oriente), expected to be completed in 2015 with an estimated cost of 37,465 million pesos, and a capacity of $150 \mathrm{~m}^{3} \mathrm{~s}^{-1}$ (CONAGUA, 2015). The second project is a mega-treatment plant called Atotonilco, with a capacity to treat $60 \%$ of the wastewater produced in the MCMA, is mainly intended for agricultural use. From the above characterization it is clear that water resource management in the MCMA suffers from efficiency, equity and unsustainability problems that make it less resilient to climate change effects.

\section{Methodology}

\subsection{Impacts of Climate Change on Water Resources}

In this study, historical records of temperature, precipitation and evapotranspiration from the Mexico National Weather Service for the period from 1959 to 1988 were used. Simulations of potential evapotranspiration (ET) were produced using the Hargreaves equation. This equation was selected given the lack of climatic variables for most of the available meteorological stations (Droogers and Allen, 2002; Hargreaves and Allen, 2003). ET (mm day $^{-1}$ ) calculations were computed using daily historic time series of mean, minimum and maximum temperature $\left({ }^{\circ} \mathrm{C}\right)$ and extraterrestrial radiation $\left(\mathrm{Wm}^{-2}\right)$ taken from meteorological 
tables (Allen et al., 1998). To validate the method, ET values were computed for the historic period and the results were compared with the reported historic values. The calculated ET values had a close correlation to the historic data and the method was accepted to calculate ET values for the $20 \mathrm{c} 3 \mathrm{~m}$ experiment and for the future scenarios. An adjusted version of the Penman-Grindley water balance was used to calculate the actual evapotranspiration (AE) and effective precipitation or hydrological excess (Hxr) available for aquifer recharge or runoff (Herrera-Pantoja and Hiscock, 2008). A soil classification for the MCMA (INEGI, 2000) and soil infiltration capacity data (Ortiz and Ortiz, 1990) were applied to indicate the rate at which soil moisture deficit (SMD) and hydrological excess occur. AE was computed as a function of soil water content, vegetation characteristics and ET. To avoid underestimation, the water balance for the MCMA was run with a daily time step (Howard and Lloyd, 1979).

In order to examine the impacts of climate change on the water balance for the MCMA, the daily outputs of the General Circulation Model GFDLCM2, produced by the National Oceanic and Atmospheric Administration (NOAA) and the Geophysical Fluid Dynamics Laboratory with a resolution of 2 x 2.5 degrees, obtained from the WCRP CMIP3 multi-model dataset, were used. The GFDLCM2 model was selected to perform the future simulations given that it best replicated the observed temperature and precipitation data for the region, according to the results of previous series of studies carried out by the Virtual Center on Climate Change for Mexico City (http://www.cvcccm-atmosfera.unam.mx). Two gas emissions scenarios, from the IPCC SRES (IPPC, 2001), were explored: the B1 and the A1B. The B1 is a low gas emissions scenario, which emphasizes environmental sustainability, socioeconomic global solutions, and moderate growth population. The A1B scenario is a higher gas emissions scenario, characterized by rapid economic growth, a balanced energy use of fossil fuel and clean technologies and moderate growth population. In order to downscale the GCM outputs to the basin scale, the scaling factor technique was used to adjust the baseline 20c3m (Loaiciga, 2003; Barria et al., 2015). The future series of temperature and precipitation simulated by the GFDLCM 2 model were perturbed with the computed factors calculated for the baseline and the water balance values for the future simulations were calculated with the perturbed series. Finally, an analysis of the differences between the baseline experiment and future scenarios was performed to investigate the likely impact of climate change on water resources in the MCMA.

\subsection{Impacts of Climate Change on Urban Water Demand}

Modeling domestic water demand is an increasingly important issue for different purposes such as set price structures and controlling water consumption in urban areas where residential consumption predominates over that of other sectors, such as agriculture, industry and services. It has recently been acknowledged that global warming could impact domestic water demand while reducing resource supplies (Whortington and Hoffman, 2007). There is also convincing evidence to confirm that changes in temperature and precipitation patterns impact domestic water demands (Zhang and Brown, 2005; Olmstead et al., 2007; Worthington and Hoffman, 2007; Yoo et al., 2014). For instance, in Queensland, Australia, a $10 \%$ increase in rain reduces household water consumption by $1.52 \%$ while a $10 \%$ increase in temperature increases water consumption by $19.39 \%$ (Worthington et al., 2009). Another 
study in the metropolitan area of Cape Town found that a $10 \%$ temperature increase raises water consumption by $3.1 \%$, but no significant effect was found with changes in precipitation (Jansen and Schulz, 2006).

In this study, a regression analysis was undertaken to estimate how changes in temperature and precipitation patterns could impact urban water demand. Household consumption for the Federal District data was provided by the Water System of Mexico City (SACM). The analysis included a sample of 58,456 domestic consumers with metered service out of a total of 2.03 million users, for the period from 2007 to 2013. This sample included only metered service and areas with a reliable water supply, which makes it possible to track changes in household water consumption. A comparison of our sample with the general characteristics of the population might misrepresent the low-income households, because there is evidence that service deficiencies disproportionately affect poorer households (Soto and Bateman, 2006). Despite this, the biased might be reduced because there are differentiated price structures, where low income areas pay lower tariffs.

Table 1 shows that higher average household water consumption was recorded between the period from March and June, coinciding with the season of high temperatures and low or moderate rainfall, while lower water consumption was recorded in the following months from July to October, corresponding to high rainfall and medium temperatures.

Table 1. Average bimonthly household consumption for the Federal District (2007 -2013)

\begin{tabular}{|l|c|c|c|}
\hline & $\begin{array}{c}\text { Average household consumption } \\
\text { in the sample }\left(\mathrm{m}^{3}\right)^{*}\end{array}$ & $\begin{array}{c}\text { Average temperature } \\
\left({ }^{\circ} \mathrm{C}\right)\end{array}$ & $\begin{array}{c}\text { Average precipitation } \\
(\mathrm{mm})\end{array}$ \\
\hline Jan-Feb & 37.28 & 9.5 & 15.93 \\
\hline Mar-April & 38.33 & 12.1 & 38.83 \\
\hline May-Jun & 38.50 & 12.4 & 183.05 \\
\hline Jul-Aug & 35.51 & 11.6 & 267.65 \\
\hline Sept-Oct & 35.35 & 10.9 & 133.23 \\
\hline Nov-Dec & 36.22 & 9.4 & 14.08 \\
\hline
\end{tabular}

Source: Data provided by Water System of Mexico City (SACM).

Using the above mentioned procedure, water demand (D) was determined as the dependent variable and temperature and precipitation as independent variables. This takes the form of

$$
\mathrm{D}=\mathrm{f} \text { (temperature, precipitation, } \mathrm{Z} \text { ) }
$$

where $\mathrm{Z}$ is other independent variables assumed to impact domestic water demand. A regression model was developed using average household water consumption $\left(\mathrm{m}^{3}\right)$ as the dependent variable $(\mathrm{Q})$ and average temperature $(\mathrm{Tm})$ and the natural log of average precipitation $(\ln \mathrm{P})$ as the independent variables.

From Table 2 it can be seen that the effects on water consumption are positively influenced by the temperature and negatively influenced by precipitation. The coefficient of $\mathrm{Tm}$ is 1.358 , indicating that a $10 \%$ increase in temperature is associated with a $5 \%$ increase in household water consumption, while the $\operatorname{lnP}$ coefficient indicates that a $10 \%$ increase in rainfall is 


\section{Macrothink}

associated with a $1.2 \%$ decrease in the amount demanded, given that the log is read as an elasticity variable. $\mathrm{R}^{2}$ has relatively high explanatory power of 0.736 . The $\mathrm{R}^{2}$ coefficient is considered relatively high compared to other similar studies on water demand. For instance, Akuoko-Asibey et al. (1993) defined a linear regression model with an $\mathrm{R}^{2}$ of 0.53 , which included three independent variables: number of days with measurable precipitation, mean maximum weekly temperature and heating-degree days above $16^{\circ} \mathrm{C}$. Worthington et al. (2009) defined a model for Queensland, Australia, where residential water is responsive to average prices, temperature and rainfall, with an adjusted $\mathrm{R}^{2}$ of 0.39 . Other studies have found higher adjusted $\mathrm{R}^{2}$, for instance Renwick and Green (2000) found Adjusted $\mathrm{R}^{2}$ of 0.91 for a model with multiple variables that included temperature and precipitation.

Table 2. Regression model of household water consumption

\begin{tabular}{|c|c|c|}
\hline Variable & Coefficient & Std. Error \\
\hline $\mathrm{Q}$ & $27.056^{* *}$ & 4.023 \\
\hline $\mathrm{Tm}$ & $1.358^{*}$ & 0.482 \\
\hline $\ln \mathrm{P}$ & $-1.238^{*}$ & 0.488 \\
\hline
\end{tabular}

Significance level: $* \mathrm{p}<0.01 ; * * \mathrm{p}<0.05$

The estimated regression coefficients were used to simulate the observed period. There was a reasonable fit between simulated and observed average consumption for the period 2007-2013 (Figure 2). Therefore, the model was considered satisfactory for predictive analyses and used to simulate average household water consumption expected for the two future scenarios as regards to projected changes in temperature and precipitation. The advantage of this approach is that it considers the changes in these climate variables simultaneously.

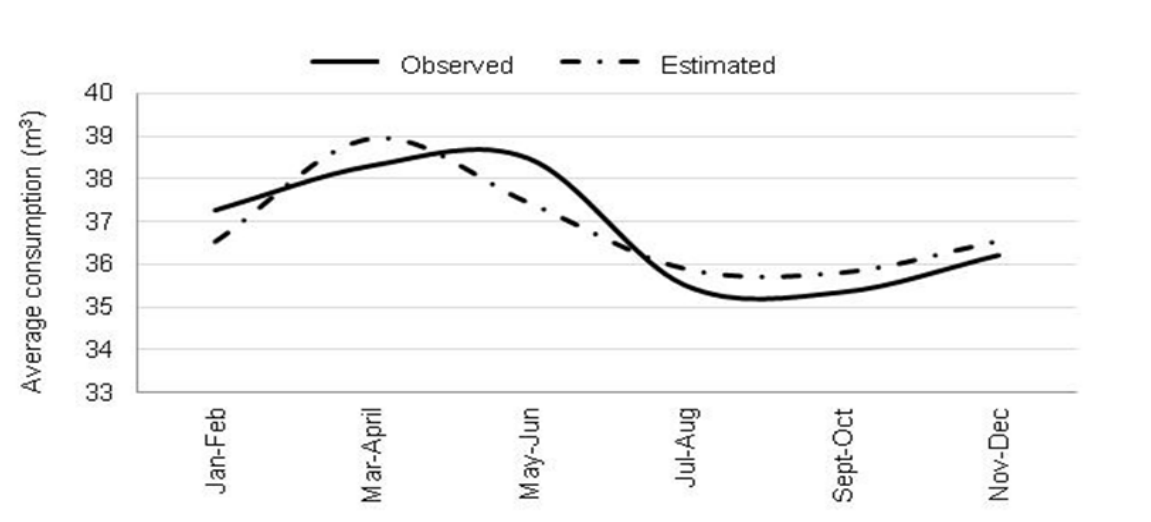

Figure 2. Comparison of average bimonthly consumption $\left(\mathrm{m}^{3}\right)$ for the observed period 2007-2013 with the estimated consumption.

\subsection{Assessing The Vulnerability To Climate Change}

In order build their adaptive capacity and support water management plans and strategies, megacities need to identify their main vulnerabilities. In this study, a review of relevant 
literature on water resources in the MCMA helped make a qualitative characterization. This characterization together with an assessment of current trends and likely impacts of climate change supported the identification of the main vulnerabilities of the current system to climate change (EPA, 2011). Vulnerabilities exposed to several climate change impacts were prioritized more highly than others (EPA, 2011).

\section{Results}

\subsection{Future Climate Simulations}

The simulations performed for the MCMA using the GFDLCM2 climate model showed that temperatures for the period 2046-2081 could increase between $3^{\circ} \mathrm{C}$ and $4^{\circ} \mathrm{C}$. Analysis of seasonal temperature anomalies for the period 2046-2081 under the A1B scenario simulated positive anomalies in $75 \%$ of the years during the summer season, showing that maximum temperature values could be up to $3^{\circ} \mathrm{C}$ warmer than average. During the winter season $72 \%$ of the years showed positive temperature anomalies while minimum temperatures could increase by $4^{\circ} \mathrm{C}$. Under the B1 scenario, only $12.5 \%$ of the summers displayed positive anomalies of approximately $1^{\circ} \mathrm{C}$ above average. Conversely, $80 \%$ of the winter seasons showed positive anomalies with minimum temperatures up to $5^{\circ} \mathrm{C}$ warmer than average. Under future warmer climate total mean annual precipitation for the MCMA could decrease by $20 \%$ under the A1B emissions scenario and increase by $23 \%$ under the B 1 scenario, with more significant changes during the rainy season (Figures 3). The B1 scenario also showed an increase of about $150 \%$ in events with rainfall intensity of more than $60 \mathrm{~mm}$ in 24 hours and an increase of almost $200 \%$ in the frequency of events with an intensity of over $70 \mathrm{~mm}$ in 24 hours (Figure 4). The A1B scenario indicated a $20 \%$ decrease in mean annual precipitation and an increase of $7 \%$ in potential evapotranspiration that would result in a decrease of $6 \%$ in mean annual effective precipitation for the MCMA. On the other hand, the B1 scenario showed an increase of $23 \%$ in precipitation during the wet season, which would result in an increase of $66 \%$ in mean annual effective precipitation (Figure 5).

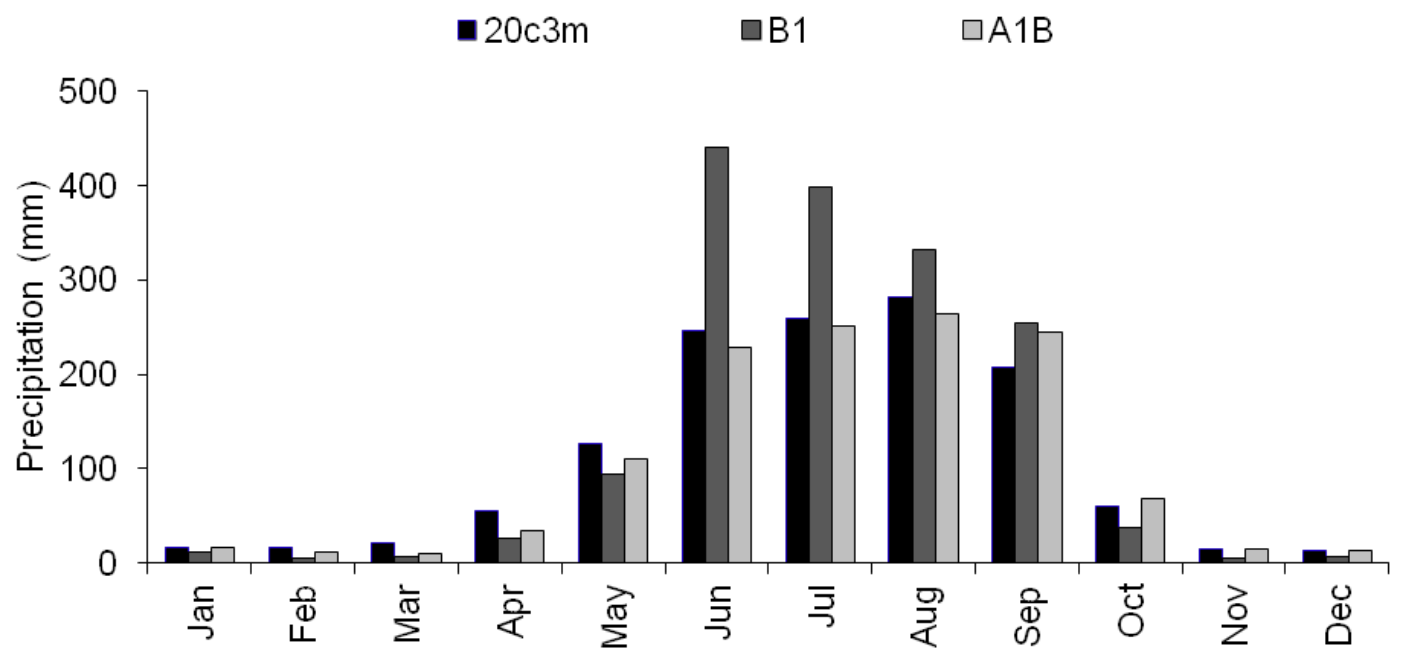

Figure 3. Total mean annual precipitation simulated for the MCMA by the GFDLCM2 climate model for the baseline period 20c3m (1961-1990) and the future period 2046-2085 
under the A1B and B1 emissions scenarios.

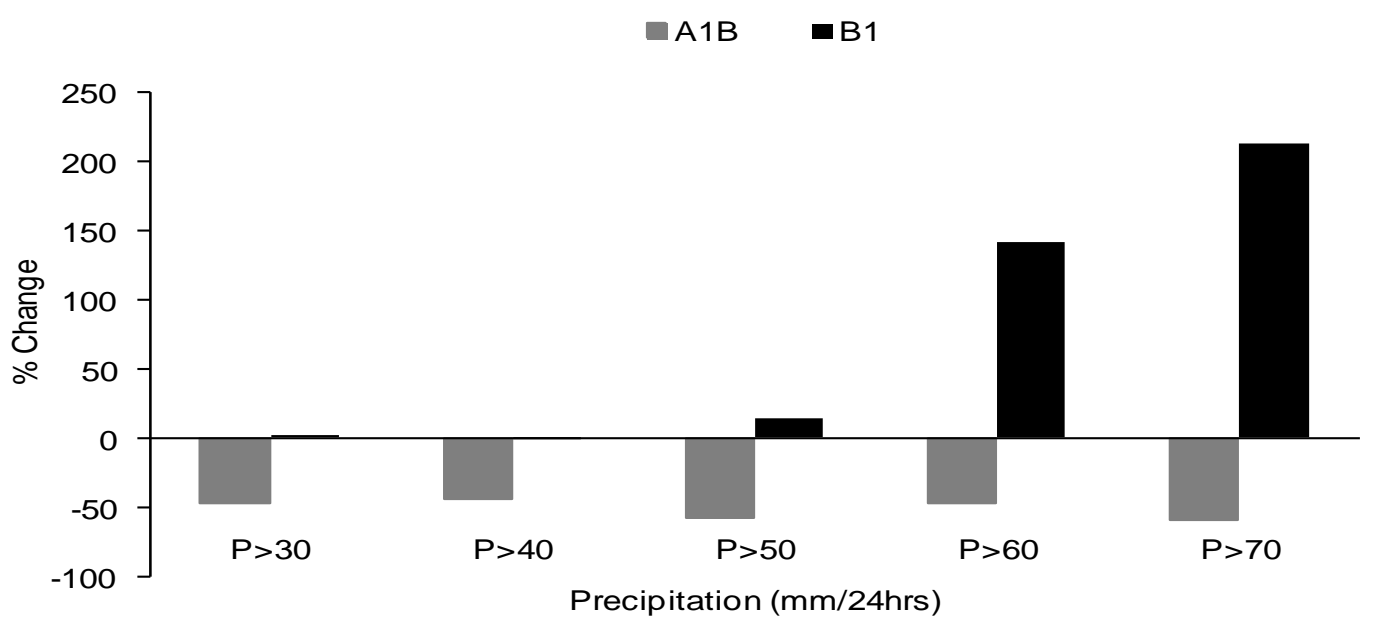

Figure 4. a) Percentage change in the number of extreme precipitation events for the MCMA for the period 2046-2085 under the A1B and B1 emissions scenarios.

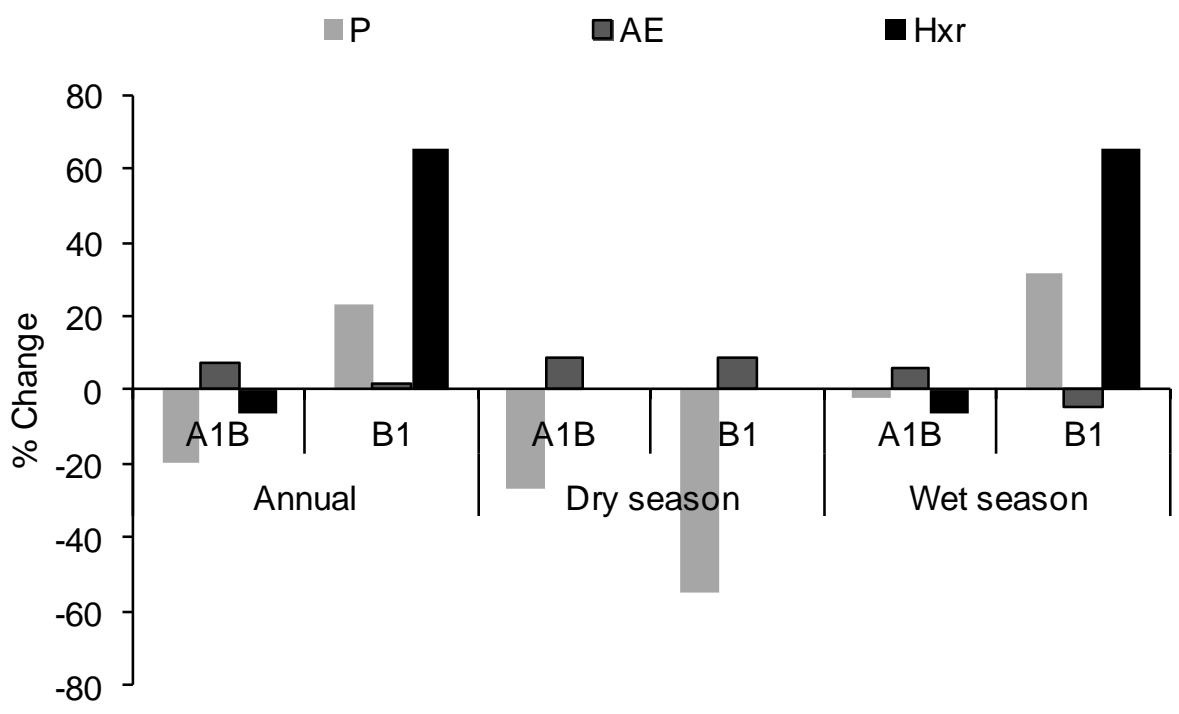

Figure 5. Percentage changes in mean annual precipitation (P), actual evapotranspiration (AE) and potential effective precipitation (Hxr) during the dry and wet seasons, simulated for the

MCMA for the future period 2046-2085 under the A1B and B1 emissions scenarios.

At present, rainwater discharged through the drainage pipe system in the northern-urbanized area is $16.3 \mathrm{~m}^{3} \mathrm{~s}^{-1}$. The predicted increase in the frequency and intensity of precipitation events, projected under the B1 scenario, highlights a significant rise in flooding events given the reduced infiltration through sealed surfaces and insufficient drainage infrastructure. Therefore, the amount of water discharged could increase by $27 \mathrm{~m}^{3} \mathrm{~s}^{-1}$. The estimated increase between $150 \%$ and $200 \%$ in events with rainfall intensity of more than $60 \mathrm{~mm} \mathrm{~d}^{-1}$ and $70 \mathrm{~mm}$ $\mathrm{d}^{-1}$ respectively, draw attention to the critical impacts these changes may have due to flooding events on many sectors of society. 


\subsection{Implications on Water Demand}

Estimated regression coefficients were used to project the average household water consumption expected for the two scenarios in the MCMA. The B1 scenario simulated an increase in 5 out of 6 bimonthly periods in household water consumption. Water consumption could increase from $0.82 \%$ to $5 \%$, except from July to August, when it would decrease by $3.1 \%$, due to high rainfall. Under the A1B scenario, higher household water consumption levels could be expected throughout the whole year with an increase of $2.9 \%$ during the fourth bimonthly period and as high as $6.3 \%$ during the second bimonthly period of the dry season (Figure 6).

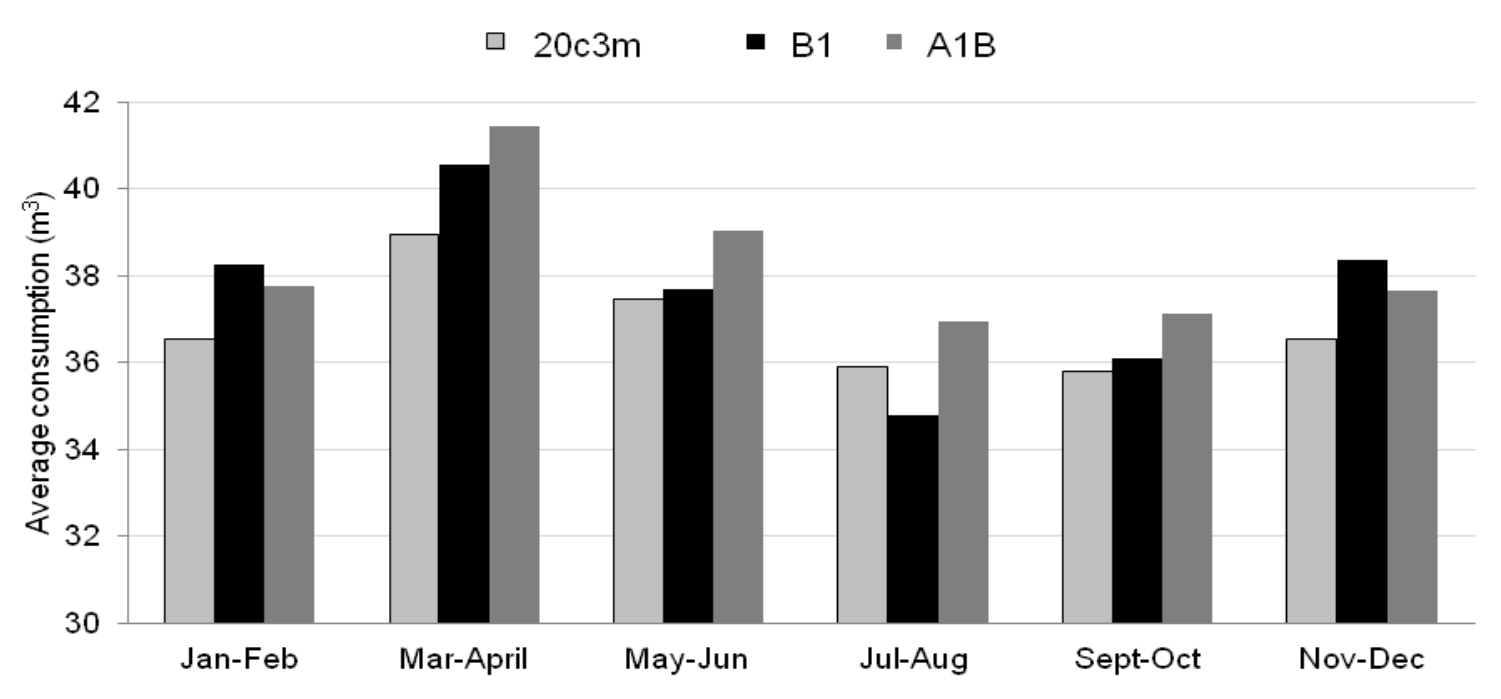

Figure 6. Average bimonthly consumption $\left(\mathrm{m}^{3}\right)$ simulated for the MCMA for the baseline period 20c3m and the future period 2046-2085 under the A1B and B1 emissions scenarios.

The impact of higher domestic water demand in these two scenarios would require the authorities to access new water sources. Current domestic use accounts for approximately $68 \%$ of the total water consumed in the Federal District (integrating the pipe leak effect), equivalent to $21.7 \mathrm{~m}^{3} \mathrm{~s}^{-1}$. Considering an optimistic water management policy scenario in which the water supply service improves so that every household would enjoy a reliable water supply by the middle of this century, regardless of seasonal changes, under the B1 scenario, the city would need to access $4.7 \%$ more water, coinciding with the dry season at the beginning of the year and about the same volume 5\%, at the end of the year. Under the A1B gas emissions scenario, water consumption is likely to increase throughout the whole year, particularly during the second bimester with a likely increase of an additional $6.3 \%$, while other bimesters would require increases of at least another $2.9 \%$.

\subsection{Vulnerabilities to Climate Change}

According to the performed analysis, water supply in the MCMA, is highly vulnerable. Water supply depends mainly on groundwater. Groundwater accounts for approximately $70 \%$ of water resources in the MCMA and the rest is imported from the Cutzamala System. Estimations have indicated that water extraction exceeds the natural aquifer recharge capacity 
by approximately $22 \%$ (SACM, 2012). At present, the water supply service is under high pressure given the population growth, urbanization of groundwater recharge zones and the regional competition for water resources. As a consequence, a water deficit of at least 25.1 $\mathrm{m}^{3} \mathrm{~s}^{-1}$ has been predicted by 2030 (World Bank, 2013). In the past, the susceptibility of the water supply system has been experienced during dry periods, i.e. in August 2009, when total reservoir storage went down in the Cutzamala System and the water supply service was reduced by $25 \%$. The authorities have considered a series of measures designed to improve the efficiency of the current system, including projects for reducing leaking pipes, treating wastewater, undertaking ecological conservation actions, and reinforcing the sewerage system. The estimated cost is 661,430.00 USD for the entire MCMA (World Bank, 2013) and 133,578 USD for the Federal District alone by 2030 (SACM, 2012; World Bank 2013). Unfortunately, several of these measures still do not receive sufficient funding for effective implementation. The predicted increase in temperature between $3^{\circ} \mathrm{C}$ and $4^{\circ} \mathrm{C}$ and changes in precipitation patterns and evapotranspiration are expected to increase household water demand for both scenarios, between $0.8 \%$ and $6.3 \%$, which in turn could be intensified by the heat island effect produced by a constant modification of land surfaces, buildings and human activities (Smith, et al., 2009). The future scenarios of climate change simulated in this study, suggest that mean annual effective precipitation, available for groundwater recharge or runoff, could decrease by $6 \%$ under the A1B gas emissions scenario. In addition, the predicted occurrence of extreme events could also have serious implications for water supply. Consequently, climate change is expected to exacerbate water supply vulnerability and it is anticipated that if no action is undertaken most households will face severe, systematic water supply shortfalls.

The MCMA is also highly vulnerable to floods because of rapid urbanization, ecological deterioration, groundwater overexploitation, poor sanitation and inadequate policy responses. Mexico City's flooding problem is worsening due to a lack of maintenance in the 60 year old deep drainage system (Aragon-Duran, 2007). The drainage operation became a major concern since the past decade when the risk of major flooding in the city increased due to the land subsidence, and a sewage deficit of $12.9 \mathrm{Mm}^{3} \mathrm{~d}^{-1}$ caused by population growth. The vulnerability of the MCMA to flooding has been clearly evident in 1985, 2005, 2009, 2010 and 2011, when severe precipitation events with high intensities caused floods that broke the western sewerage section and affected public infrastructure and widespread damage of lives and property (CONAGUA, 2009; SACM, 2012a). These events made the authorities aware of the need to undertake prevention and financial disaster risk management. Consequently, in 1996, the government of Mexico established a Natural Disaster Fund (FONDEN) to support the rehabilitation of infrastructure, and in 2006, when the fund began to be insufficient, it transferred its post-disaster liabilities to international capital markets as "Cat Bonds" as a mechanism for protecting against the financial risks of extreme catastrophes (Hochrainer and Mechler, 2011). According to the B1 scenario total mean annual precipitation could increase by $23 \%$ under the B1 scenario, with more significant changes during the rainy season. It is also expected that climate change will lead to a rise in the frequency and intensity of extreme precipitation events, increasing the vulnerability of the system. Therefore, decision-makers should consider flexible adaptation strategies and planning that allow for adjustment under 
different scenarios (Herrera-Pantoja and Hiscock, 2015).

\section{Discussion and Conclusions}

In this study, the MCMA is presented as a case study in order to investigate the future impact of climate change on water resource management in megacities in developing countries. Water supply and flooding were identified as the main vulnerabilities of the current system to climate change because of the several impacts they are exposed to. These results agree with other investigations in which it is concluded that the high rate of population growth combined with decreasing water resources posed by climate change is expected to increase water scarcity in many large urban areas (Jenerette and Larsen, 2006; Marsily, 2007; Vairavamoorthy et al., 2008). However, it is important to notice that the degree of vulnerability may vary from place to place, because the impacts depend on the characteristics inherent to the exposed system (IPCC, 2007). As urbanization increases the number of individuals, infrastructure, and economic losses vulnerable to climate change also increases (Rosenzweig and Solecki, 2014). Therefore, each megacity will have unique vulnerabilities and assessing these vulnerabilities is the first step in considering adaptation.

In developing countries the vulnerability to hydrometeorological events is largely due to deficient development (Bolognesi, 2015). Megacities in developing countries seldom consider disaster prevention in the planning process mainly because of budget constraints (Hochrainer and Mechler, 2011). Therefore, vulnerability assessment in developing countries, to assist policymakers, is a huge challenge (Cross, 2001). For example Jakarta is one of the most vulnerable cities to climate change; yet local governments are not aware of the risks they are facing (Firman, 2011). Learning from crises and creating opportunities through adaptive plans is one way to develop adaptive responses for an uncertain climate change (Wilkinson, 2011). For example, the MCMA developed a comprehensive risk management strategy and invested in the prevention and reduction of loss from disaster, increasing its resilience to extreme events, after several extreme flood events (Hochrainer and Mechler, 2011). New York, incorporated climate change risks in the rebuilding process after Hurricane Sandy (Rosenzweig and Solecki, 2014). An investigation carried out in Hyderabad, India showed that investment in water infrastructure is one of the best ways of reducing the impacts of extreme events and supporting adaptation in complex urban environments (Reckien, 2014). It is clear that some of these policies are a somewhat autonomous adaptation, because the adjustments do not constitute a conscious response to climate change, but rather a generated response to solve current problems. Nevertheless, these responses increase their resilience and reduce their vulnerability to climate change.

There are several adaptation strategies proposed in the literature that megacities can approach to develop their adaptive capacity in the context of sustainable development. For instance, leading urban growth away from hazard zones can lessen likely losses caused by floods and droughts (Childers et al., 2014; Güneralp, 2015). Water recycling and reuse of treated wastewater could be adopted to improve water demand and contribute to solving environmental and health problems (Kalavrouziotisa and Apostolopoulosb, 2007). A rainwater harvesting system would have the advantage of increasing water resource 
availability during drought periods, decreasing dependence on external sources as well as reducing flooding events (Mahmoud et al.,2014). Megacities should also consider the protection and restoration of ecosystems that are important water sources, since they are vital for sustainable development (WWF, 2011). Authorities could also exploit the benefits of increasing precipitation events, especially in terms of potential aquifer recharge and surface storage (Hossain, 2013). It is also important to promote awareness and increasing local knowledge and practices that reduce the population vulnerability (Jabareen, 2013). Greater response capacity would limit physical damage, while greater awareness, coupled with better institutions could reduce the impact of extreme climate events and a decline water sources.

From this case study, one can conclude that megacities are particularly threatened by climate change due to high population densities, inadequate urban design, poor infrastructures, and deficient technical expertise and policies. The results presented in this paper may help decision-makers to better understand the implications of climate change on water resource management. Despite the uncertainty of models projections, future climate change scenarios can be used as a flexible guide to identify vulnerabilities and support strategic adaptation planning. In order to increase their adaptive capacity and resilience to the effects of an uncertain climate change, megacities should consider implementing an IWRM approach to create opportunities through adequate policies, new technologies, flexible frameworks and innovative actions that would reduce the shortcomings and vulnerabilities of the current system.

\section{Acknowledgement}

This research was funded by Mexico City's Virtual Centre on Climate Change (CVCCCM) and the Institute of Science and Technology of the Federal District (ICyTDF). We appreciate the technical assistance provided by the Mexico City Water System (SACM) the World Climate Research Program (WCRP) for providing data from coupled Atmosphere-Ocean General Circulation Models, Justin Radcliffe and the reviewer for their thorough reviews that considerably helped to improve this paper.

\section{References}

Aguilar, AG. (2008). Peri-urbanization, illegal settlements and environmental impact in Mexico City. Cities, 25, 133-145. http://dx.doi.org/10.1016/j.cities.2008.02.003

Akuoko-Asibey A, Nkemdirim LC, \& Draper D. (1993). The impacts of climatic variables on seasonal water consumption in Calgary, Alberta. Canadian Water Resources Journal / Revue canadienne des ressources hydriques, 18, 107-116. Doi: 10.4296/cwrj1802107

Aragón-Duran F. (2007). Urbanisation and flood vulnerability in the peri-urban interface of Mexico City. Disasters, 31, 477-94. http://dx.doi.org/10.1111/j.1467-7717.2007.01020.x

Barria P, Walsh KJE, Peel MC, \& Karoly D. (2015). Uncertainties in runoff projections in southwestern Australian catchments using a global climate model with perturbed physics. Journal of Hydrology, 529, 184-199. http://dx.doi.org/10.1016/j.jhydrol.2015.07.040

Bates BC, Kundzewicz ZW, Wu S, \& Palutikof JP. (2008). Climate Change and Water. 
Technical Paper of the Intergovernmental Panel on Climate Change. IPCC Secretariat, Geneva. [Online] Available: http://ipcc.ch/pdf/technical-papers/climate-change-water-en.pdf. (Dec 10, 2015)

Bolognesi T. (2015). The water vulnerability of metro and megacities: An investigation of structural determinants. Natural Resources Forum, 39, 123-133. http://dx.doi.org/10.1111/1477-8947.12056

Cisneros-Iturbe H, \& Dominguez-Mora R. (2007). The detention dams system of Mexico City, new challenges. Novatech, 1565-1572. [Online] Available: http://documents.irevues.inist.fr/bitstream/handle/2042/25185/1565_142cisnerosill.pdf?seque nce $=1$. (Dec 10, 2015)

Childers DL, Pickettb STA, Grovec JM, Ogden L, \& Whitmer A. (2014). Advancing urban sustainability theory and action: Challenges and opportunities. Landscape and Urban Planning, 125, 320-328. http://dx.doi.org/10.1016/j.landurbplan.2014.01.022

CONAGUA. (2009). La memoria del agua. Trabajos, retos y logros de la Comisión Estatal de Aguas de Querétaro 2001-2009. (Water memory. Works, challenges and achievements of Querétaro Water Commission 2001-2009). Comision Estatal de Aguas. Armida y Asociados S.A. de C.V., Queretaro, Mexico.

CONAGUA. (2003). Plan hidráulico regional 2002-2006. Aguas del Valle de México y sistema Cutzamala, Región XIII. (Hydraulic regional plan 2002-2006. Water of the Valley of Mexico and Cutzamala system, Region XIII). Comisión Nacional del Agua, Mexico, DF.

CONAGUA. (2015). Strategic projects, drinking water, sewerage and sanitation. [Online] Available: http,//www.conagua.gob.mx/english07/publications/StrategicProjects.pdf.

Cross JA. (2001). Megacities and small towns, Different perspectives on hazard vulnerability. Environmental Hazards, 3, 63-80. http://dx.doi.org/10.1016/S1464-2867(01)00020-1

Droogers P, \& Allen RG. (2002). Estimating reference evapotranspiration under inaccurate data conditions. Irrigation and Drainage System, 16, 33-45. http://dx.doi.org/10.1023/A:1015508322413

Ekström M, Kuruppu N, Wilby RL, Fowler HJ, Chiew FHS., Dessai S, Young WJ. (2013). Examination of climate risk using a modified uncertainty matrix framework-Applications in the water sector. Global Environmental Change, 23, 115-129. http://dx.doi.org/10.1016/j.gloenvcha.2012.11.003

EPA. (2011). Climate Change Handbook for Regional Water Planning. US Environmental Protection Agency, Region 9 California Department of Water Resources. [Online] Available: http,//www.water.ca.gov/ climatechange /CCHandbook.cfm. (Dec 10, 2015)

Farley KA, Tague C, Grant GE. (2011). Vulnerability of water supply from the Oregon Cascades to changing climate: Linking science to users and policy. Global Environmental Change, 21, 110-122. http://dx.doi.org/10.1016/j.gloenvcha.2010.09.011 


\section{Mll Macrothink}

Environmental Management and Sustainable Development

ISSN 2164-7682 2016, Vol. 5, No. 1

Firman T, Surbakti IM, Idroes IC, Simarmata HA. (2011). Potential climate-change related vulnerabilities in Jakarta: Challenges and current status. Habitat International, 35, 372-378. http://dx.doi.org/10.1016/j.habitatint.2010.11.011

Giorgi F, Jones C, Asrar G. (2009). Addressing climate information needs at the regional level: the CORDEX framework. The journal of the World Meteorological Organization, 58, 175-184. [Online] Available: http://www.wmo.int/pages/publications/bulletinarchive/ archive/58_3_en/documents/bulletin.pdf. .(Dec 10,2015)

Güneralp B, Güneralp I, Liu Y. (2015). Changing global patterns of urban exposure to flood and drought hazards. Global Environmental Change, 31, 217-225. http://dx.doi.org/10.1016/j.gloenvcha.2015.01.002

Hargreaves GH, \& Allen RG. (2003). History and evaluation of Hargreaves evapotranspiration equation. Journal of Irrigation and Drainage Engineering, 129, 53-63. http://dx.doi.org/10.1061/(ASCE)0733-9437(2003)129:1(53)

Hebbert, M., \& Jankovic, V. (2013). Cities and climate change, the precedents and why they matter. Urban Studies, 50, 1332-1347. http://dx.doi.org/10.1177/0042098013480970

Herrera-Pantoja M, \& Hiscock KM. (2008). The effects of climate change on potential groundwater recharge in Great Britain. Hydrological Processes, 22, 73-86. doi: 10.1002/hyp.6620

Herrera-Pantoja M, \& Hiscock KM. (2015). Projected impacts of climate change on water availability indicators in a semi-arid region of central Mexico. Environmental Science \& Policy, 54, 81-89. http://dx.doi.org/10.1002/hyp.6620

Hochrainer S, \& Mechler R. (2011). Natural disaster risk in Asian megacities: A case for risk pooling? Cities, 28, 53-61. http://dx.doi.org/10.1016/j.cities.2010.09.001

Hossain F, Degu AM, Woldemichael AT, Yigzaw W, Mitra C., Shepherd JM, Siddique-E-Akbor A. H. M. (2013). 5.25 - Water Resources Vulnerability in the Context of Rapid Urbanization of Dhaka City (a South Asian Megacity). Reference Module in Earth Systems and Environmental Sciences. Climate Vulnerability, 5, 393-404. http://dx.doi.org/10.1016/B978-0-12-384703-4.00540-2

Howard KWF, \& Lloyd JW. (1979). The sensitivity of parameters in the Penman evaporation equation and direct recharge balance. Journal of Hydrology, 41, 329-344. http://dx.doi.org/10.1016/j.envsci.2015.06.020

Hunt A, \& Watkiss P. (2011). Climate change impacts and adaptation in cities: A review of the literature. Climatic Change, 102, 13-49. http://dx.doi.org/10.1007/s10584-010-9975-6

INEGI. (2000). Carta edafológica, escala 1, 250000 (Edaphological letter, scale 1, 250 000). Mexico.

INEGI. (2010). Censo de población y vivienda 2010 (Census of Population and Housing 2010). Instituto Nacional de de Estadistica, Geografia e Informatica. Mexico. 
IPCC. (2007). Climate change 2007, Synthesis report. Summary for policymakers. An Assessment of the Intergovernmental Panel on Climate Change. Cambridge University Press, Cambridge.

[Online]

Available:

https://www.ipcc.ch/pdf/assessment-report/ar4/syr/ar4_syr_spm.pdf. (Dec 10, 2015)

IPCC. (2012). Managing the risks of extreme events and disasters to advance climate change adaptation. A special report of working groups I and II of the Intergovernmental Panel on Climate Change. UK, Cambridge University Press. [Online] Available: https://www.ipcc.ch/pdf/special-reports/srex/SREX_Full_Report.pdf. (Dec 10, 2015)

Jansen A, \& Schulz CE. (2006). Water demand and the urban poor: A study of the factors influencing water consumption among households in Cape Town, South Africa. South African Journal of Economics, 74, 11-1. http://dx.doi.org/10.4314/wsa.v41i2.09

Jabareen Y. (2013). Planning the resilient city, Concepts and strategies for coping with climate change and environmental risk. Cities, 31, 220-229. http://dx.doi.org/10.1016/j.cities.2012.05.004

Jenerette GD, \& Larsen L. (2006). A global perspective on changing sustainable urban water supplies. Global and Planetary Change, 50, 202-211. http://dx.doi.org/10.1016/j.gloplacha.2006.01.004

Kalavrouziotisa I. K, \& Apostolopoulosb C A. (2007). An integrated environmental plan for the reuse of treated wastewater effluents from WWTP in urban areas. Building and Environment, 42, 1862-1868. http://dx.doi.org/10.1016/j.buildenv.2006.07.016

Loaiciga HA. (2003). Climate change and ground water. Annals of the Association of American Geographers, 93, 30-41. http://dx.doi.org/10.1111/1467-8306.93103

Lopez-Quiroz P, Doin MP, Tupin F, Briole P, \& Nicolas JM. (2009). Time series analysis of Mexico City subsidence constrained by radar interferometry. Journal of Applied Geophysics, 69, 1-15. http://dx.doi.org/10.1016/j.jappgeo.2009.02.006

Luege-Tamargo JL. (2011). Climate change and flooding in the Valley of Mexico. [Online] Available: http,//www.conagua.gob.mx/CONAGUA07/Contenido/Documentos/ EL\%20CAMBIO\%20CLIM\%C3\%81TICO\%20Y\%20LAS\%20\%20INUNDACIONES\%20E N\%20EL\%20VALLE\%20DE\%20M\%C3\%89XICO.pdf. (Dec 10, 2015)

Mahmoud WH, Elagib NA, Gaese H, \& Heinrich J. (2014). Rainfall conditions and rainwater harvesting potential in the urban area of Khartoum. Resources. Conservation and Recycling, 91, 89-99. http://dx.doi.org/10.1016/j.resconrec.2014.07.014

Marín LE, Escolero-Puentes O, \& Trinidad-Santos A. (2002). Physical Geography, Hydrogeology and Forest Soils of the Basin of Mexico. In, Fenn M, de Bauer L, Hernández-Tejeda $\mathrm{T}$ (ed) Urban air pollution and forests. Resources at risk in the Mexico City air basin. Ecological studies, Springer-Verlag, New York. http://dx.doi.org/10.1007/978-0-387-22520-3_3

Marsily G. (2007). An overview of the world's water resources problems in 2050. 
http://dx.doi.org/10.1016/S1642-3593(07)70180-5

Miller K, \& Yates D. (2005). Climate change and water resources, A primer for municipal water providers. National Center for Atmospheric Research and Awwa Research Foundation, USA.

Olmstead SM, Hanemann MW, \& Stavins RN. (2007). Water demand under alternative price structures. Journal of Environmental Economics and Management, 54, 181-198. http://dx.doi.org/10.3386/w13573

Ortega-Guerrero A, Rudolph DL, \& Cherry JA. (1999). Analysis of long-term land subsidence near Mexico City, Field investigations and predictive modeling. Water Resources Research, 35, 3327-3341. http://dx.doi.org/10.1029/1999WR900148

Ortiz VB, \& Ortiz SCA. (1990). Soil science. Autonomous University of Chapingo, Mexico.

Reckien D. (2014). Weather extremes and street life in India-Implications of Fuzzy Cognitive Mapping as a new tool for semi-quantitative impact assessment and ranking of adaptation $\begin{array}{llll}\text { measures. Global Environmental } & \text { Change, }\end{array}$ http://dx.doi.org/10.1016/j.gloenvcha.2014.03.005

Renwich ME, \& Green RD. (2000). Do residential water demand side management policies measures up? An analysis of eight California water agencies. Journal of Environmental Economics and Management, 40, 37-55. doi:10.1006/jeem.1999.110

Rosenzweig C, \& Solecki W. (2014). Hurricane Sandy and adaptation pathways in New York: Lessons from a first-responder city. Global Environmental Change, 28, 395-408. http://dx.doi.org/10.1016/j.gloenvcha.2014.05.003

Pelling M. (2011). Adaptation to Climate Change. Routledge, New York.

SACM. (2012). Programa de gestión integral de los recursos hídricos, visión 20 años (Program of integral management of water resources, vision 20 years). Sistema de Aguas de la Ciudad de México, Gobierno del Distrito Federal.

SACM. (2012a). El gran reto del agua en la ciudad de México. Pasado, presente y perspectivas de solución para una de las ciudades más complejas del mundo (The great challenge of water in Mexico City. Past, present and solution perspectives for one of the most world complex cities). Sistema de Aguas de la Ciudad de México, Gobierno del Distrito Federal.

SACM. (2008). Volumen anual de agua entregada de fuentes locales y federales (Annual volumes of water delivered from local and federal sources). Dirección de Sectorización y Automatización, Sistema de Aguas de la Ciudad de México.

Smith C, Lindley S, \& Levermore. (2009). Estimating spatial and temporal patterns of urban anthropogenic heat fluxes for UK cities, the case of Manchester. Theoretical and Applied Climatology, 98, 19-35. http://dx.doi.org/10.1007/s00704-008-0086-5 
Soto Montes de Oca G. (2008). Diagnóstico sobre la situación del riesgo y vulnerabilidad de los habitantes del Distrito Federal al no contar con el servicio de agua potable. (Diagnosis of risk and vulnerability situation of the Federal District inhabitants due to not having access to the water supply service). Procuraduría Ambiental y del Ordenamiento Territorial del Distrito Federal (PAOT), Mexico DF. [Online] Available: http,//centro.paot.org.mx/documentos/paot/estudios/Agua_potable_en_el_Distrito_ Federal_riesgo_y_vulnerabilidad.pdf. (Dec 10, 2015)

Soto MG \& Bateman IJ. (2006). Scope sensitivity in households' willingness to pay for maintained and improved water supplies in a developing world urban area: Investigating the influence of baseline supply quality and income distribution upon stated preferences in Mexico City. Water Resources Research, 42, 1-15. http://dx.doi.org/10.1029/2005WR003981

Stern N. (2006). Stern review. The economics of climate change. HM Treasury, London.

Tortajada C. (2006). Who has access to water? Case study of Mexico City metropolitan area. Human Development Report 2006. Occasional paper- UNDP Human Development reports. [Online] Available:

http://hdr.undp.org/en/content/institucionalidad-para-el-desarrollo-humano

United Nations. (2009). Brazil / Water and sanitation: "In a land with great potential and deep contrast, nobody must be left behind" - UN expert . United Nations, Human Rights. [Online] Available: http,//www.ohchr.org/EN/NewsEvents/Pages/DisplayNews.aspx? NewsID=14131\&\#sthash.Ot4zBEw9.dpuf (Dec 10, 2015)

UNHABITAT. (2008). State of the World's Cities 2010/11. Bridging the Urban Divide. United Nations Human Settlements Programme (UN-HABITAT) \& Earthscan Publishing

UNHABITAT. (2011). Cities and climate change, global report on human settlements. United Nations Human Settlements Programme.

UNICEF and WHO. (2012). Progress on Drinking Water and Sanitation, 2012 Update. WHO/UNICEF Joint Monitoring Programme for Water Supply and Sanitation. USA. Online] Available: http://www.who.int/water_sanitation_health/publications/ 2012/jmp_ report/en/ (Dec 10, 2015)

Vairavamoorthy K, Gorantiwar SD, Pathirana A. (2008). Managing urban water supplies in developing countries - Climate change and water scarcity scenarios. Physics and Chemistry of the Earth, Parts A/B/C, 33, 330-339. http://dx.doi.org/10.1016/j.pce.2008.02.008

Wigle J. (2010). The "Xochimilco model" for managing irregular settlements in conservation land in México City. Cities, 27, 337-347. http://dx.doi.org/10.1016/j.cities.2010.04.003

Wilkinson C. (2011). Social-ecological resilience: Insights and issues for planning theory. Planning Theory, 11, 148-169. http://dx.doi.org/10.1177/1473095211426274

World Bank. (2008). Climate resilient cities. A primer on reducing vulnerabilities to climate change impacts and strengthening disaster risk management in East Asian cities. Washington, D.C. [Online] Available: http://siteresources.worldbank.org 
/INTEAPREGTOPURBDEV/Resources/Primer_e_book.pdf (Dec 10, 2015)

World Bank. ( 2012).India: Improving Urban Water Supply \& Sanitation Services. Lessons from business plans for Maharashtra, Rajasthan, Haryana and international good practices. Washington, DC. [Online] Available: http://www-wds.worldbank.org/ external/default/WDSContentServer/WDSP/IB/2012/07/13/000333037_20120713000816/Re ndered/PDF/709010ESW0v10P0C00WSSS0Report0Final.pdf (Dec 10, 2015)

World Bank. (2013). Urban water in the Valley of Mexico, a green path for tomorrow? Washington, D.C. [Online] Available: http://www.worldbank.org/en/news/feature/2013 /03/19/inefficient-use-of-water-in-the-mexico-valley-a-danger-for-future-generations (Dec 10, 2015)

Worthington A, \& HoFfman M. (2007). A State of the art review of residential water demand modelling. School of Accounting \& Finance University of Wollongon. Working Papers Series. [Online] Available: http://ro.uow.edu.au/cgi/ viewcontent.cgi?article=1319 \&context=commpapers $($ Dec 10, 2015)

Worthington AC, Higgs H, \& Hoffmann M. (2009). Residential water demand modeling in Queensland, Australia: A comparative panel data approach. Water Policy, 11, 427-441. http://dx.doi.org/10.2166/wp.2009.063

WWAP. ( 2012). Managing Water under Uncertainty and Risk. The United Nations World Water Development Report 4, World Water Assessment Programme. UNESCO, Paris. [Online] Available: http://www.unesco.org/new/fileadmin/MULTIMEDIA/HQ/SC/pdf/ WWDR4\%20Volume\%201Managing\%20Water\%20under\%20Uncertainty\%20and\% 20Risk. pdf (Dec 10, 2015)

WWF (2011). Big Cities. Big Water. Big Challenges. Water in an Urbanizing World. Report D World Wide Fund For Nature, Gland, Switzerland. [Online] Available: http://www.issuelab.org/click/download2/big_cities_big_water_big_challenges_water_in_an_ urbanizing_world (Dec 10, 2015)

Wu P, Tan M. (2012). Challenges for sustainable urbanization: a case study of water shortage and water environment changes in Shandong, China. Procedia Environmental Sciences, 13, 919-927. http://dx.doi.org/10.1016/j.proenv.2012.01.085

Yoo J, Simonit S, Kinzig AP, \& Perrings C. (2014). Estimating the price elasticity of residential water demand: The case of Phoenix, Arizona. Applied Economic Perspectives and Policy, 36, 333-350. http://dx.doi.org/10.1093/aepp/ppt054

Zhang HH, \& Brown DF. (2005). Understanding urban residential water use in Beijing and $\begin{array}{llll}\text { Tianjin, } \quad \text { China. Habitat } \quad \text { International, } & \text { 469-491. }\end{array}$ http://dx.doi.org/10.1016/j.habitatint.2004.04.002 


\section{Macrothink \\ Environmental Management and Sustainable Development \\ ISSN 2164-7682}

\section{Copyright Disclaimer}

Copyright for this article is retained by the author(s), with first publication rights granted to the journal.

This is an open-access article distributed under the terms and conditions of the Creative Commons Attribution license (http://creativecommons.org/licenses/by/3.0/). 